\title{
Management of suspected cases of soft tissue sarcoma, bone invasion: 16 Case Study
}

\section{Kemik invazyon şüphesi olan yumuşak doku sarkomu olgularına yaklaşım: 16 vaka analizi}

\author{
Güray Toğral' ${ }^{1}$ Bedii Şafak Gürgör ${ }^{1}$ \\ Ankara Onkoloji Eğitim ve Araştırma Hastanesi Ortopedi ve Travmatoloji Bölümü, Ankara
}

Dergiye Ulaşma Tarihi: 08.11.2018 Dergiye Kabul Tarihi: 25.01.2019 Doi: 10.5505/aot.2019.09226

\section{ÖZET}

GIRIŞ̧ ve AMAÇ: Bu çalışmada amaç operasyon öncesi görüntüleme yöntemleri ile kemik invazyonu şüphesi olan yumuşak doku sarkomu (YDS) olgularının cerrahi tedavilerinin nasıl planlanması gerektiği ve klinik sonuçlara etkinliğinin araştırılmasıdır.

YÖNTEM ve GEREÇLER: Hastanemizde 2005-2015 yılları arasında ameliyat ettiğimiz 96 YDS olgusu retrospektif olarak incelendi. Radyolojik görüntülemeler sonrası kemik invazyonu şüphesiyle, 16 hasta çalışmaya dahil edildi. Ortalama yaş 56(18-81) idi. Bu olgulardan; 8 tanesi proksimal femur, 5 tanesi distal femur, 2 tanesi proksimal humerus ve 1 tanesi proksimal tibia yerleşimli idi. Ortalama takip süresi 22 ay(7-90) di.

BULGULAR: Histoloji 7 hastada pleomorfik sarkom, 4 hastada liposarkom, 3 hastada sinovyal sarkom, 1 er hastada alveolar soft sarkom ve maliğn periferal sinir kılıfı tümörü idi. Proksimal femur yerleşimli 8 olgudan 6'sına, 5 distal femur yerleşimli olgudan 4'üne, proksimal humerus ve tibia yerleşimli 3 hastaya kemik doku ile birlikte geniş tümör rezeksiyonu ve endoprotez ile rekonstrüksiyon yapıldı. Bu hastalardan ameliyat sonrası patoloji kayıtlarında 3 hastada tümörün kemik doku ile devamlılığının olduğu görüldü. Ortalama yaşam süresi 25(7-82) ay di. Hastaların MSTS (Musculoskeletal Tumor Society) skorları proksimal femurda 90\% (88\%-94\%), distal femurda $82 \%$ (70\%-94\%), proksimal humerusta $72 \%$ (65\%-76\%) ve proksimal tibia için \% 45 idi.

TARTIŞMA ve SONUÇ: Ameliyat öncesi görüntüleme tetkiklerinde kemik invazyon şüphesi olan YDS olgularının cerrahi tedavisinde tümör kemik doku üzerinde serbest ve periosttan sıyrılabiliyorsa, bitişik kemik doku korunarak tümör geniş olarak eksize edilmelidir. Fakat belirgin kemik dokuda destrüksiyon yapan, medullar tutulumu olan, sert-fikse ve kemiğin yarıdan fazlasını çevrelemiş olgularda ise tümör kemik doku ile birlikte çıkarılmalı ve endoprotez ile rekonstrüksiyon yapılmalıdır.

Anahtar Kelimeler: Yumuşak doku sarkomu, kemik invazyon, endoprotez

\begin{abstract}
INTRODUCTION: In this study, we aimed to analyze the clinical observation and surgical results of the patients having bone invasion suspected with imaging methods invasion with preoperatively having soft tissue sarcomas.

METHODS: We evaluated the retrospective results of 96 STS (soft tissue sarcoma) patients surgically treated between 2005-2015. 16 of these cases were suspected to have bone invasion radiologically. The mean age was 56(18-81). 8 cases were located in proximal femur, 5 were in distal femur, 2 in proximal humerus and one in proximal tibia. These patients were surgically treated with wide resection and reconstruction with endoprosthesis. Mean follow up was 22 months(7-90).

RESULTS: The histological types were: pleomorphic sarcoma in 7, liposarcoma(LS) in 4, synovial sarcoma(SS) in 3 and alveolar soft part sarcoma(ASPS) and malign peripheric nerve tumor(MPNT)in 1 patients. We recorded bone invasion in 6 of 8 proximal femur, 4 in 5 distal femur and 3 proximal humerus and 3 tibia located cases. Wound problems and infection were recorded in 3 and hip dislocation was recorded in one patient. MSTS scores were $90 \%(88 \%-94 \%)$ for proximal femur, $82 \%(70 \%-94 \%)$ for distal femur, $72 \%(65 \%-76 \%)$ for proximal humerus and $45 \%$ for proximal tibia.

DISCUSSION AND CONCLUSION: As a conclusion; periost invasion should be examined in patients with the diagnosis of softtissue sarcoma shaving bone medullar invasion with direct roentgenograms and MRI and if no periost invasion is detected, the tumor should be wriggled from the periost and the extremity should be salvaged.
\end{abstract}


Keywords: soft tissue sarcomas, bone invasion, endoprosthesis

\section{GíRIŞ}

Yumuşak doku sarkomları (YDS) vücutta kas, kemik, yağ doku gibi çeşitli bölgelerden köken alan, daha sıklıkla ekstremiteler, baş, boyun ve retroperitonyumda yerleşim gösteren nadir tümörlerdir (1). En sık ağrısız yumuşak doku şişliği şeklinde semptom gösterirler. Derin yerleşim göstermeleri nedeni ile de, çoğunlukla geç klinik belirti verirler. Kitle fark edildikten sonra görüntüleme yöntemleri ile tespit edilmeye çalış1lır. Direkt grafi, ultrasonografi, manyetik rezonans görüntüleme (MRG) bu yöntemlerden bazılarıdır. Ekstremite koruyucu cerrahi tedavinin planlanmasinda MRG kesitlerinde tümörün lokal uzanımlarının özellikle damar sinir yapıları ve kemik dokulara yakınlığının dikkatli incelenmesi önemlidir (1,2). Tanı histopatolojik olarak doğrulanmalıdır.

Yumuşak doku sarkomlarının temel tedavisi adjuvan radyoterapi (RT) ile birlikte öncelikle tümörün geniş bir şekilde çıkarıldığı ekstremite koruyucu cerrahidir. Uygulanacak bu tedavi yöntemi tümör nüksünü de engellemektedir (35). Tümörün cerrahi sınırları negatifleştirecek bir şekilde çıkarmak için cerrah, iyi bir ameliyat öncesi planlama yapmalıdır. Çünkü tümörün nüks etmesi, yetersiz cerrahi girişim ile çok yakından ilişkilidir (6). Çoğunlukla tümörün yumuşak doku cerrahi sınırı fasya, kas ya da yağ doku ile sınırlıdır. Bu durumda geniş marjinli bir cerrahi tedavi yapmak olasılığı azalmaktadır. Bazı vakalarda tümör direkt kemik yüzeye temas edebilmekte ve hatta invazyon gösterebilmektedir (7).

Damar sinir yapıları korunarak, yumuşak doku sarkomu ile birlikte tutulan kemik segment çıkartılarak, cerrahi tedavi uygulanabilmektedir. Oluşan boşluklar ise genellikle endoprotezler ile doldurulmaktadır (8). Ekstremite koruyucu cerrahi tedavinin başarılamadığı durumlarda amputasyon alternatif bir tedavi olmakla birlikte, bu da kişide oldukça yüksek bir morbidite yaratmaktadır.

$\mathrm{Bu}$ çalışmada amaç görüntüleme yöntemleri ile operasyon öncesi kemik invazyonu şüphesi olan YDS olgularının değerlendirilerek cerrahi planlamada nelere dikkat edilmesi, nasıl bir operasyon hazırlığı yapılması gerektiğinin belirtilerek, klinik gözlem ve olgu örneklerimizle bunun tedavi sonuçlarına etkilerinin tartışılmasıdır.

\section{GEREÇ VE YÖNTEM}

\section{Hasta Seçimi}

Hastanemizde 2005-2015 y1lları arasinda ameliyat ettiğimiz 96 yumuşak doku sarkomu olgusu retrospektif olarak hastane kayıtlarından incelendi. Radyolojik görüntüleme yöntemleriyle 16 vakada kemik invazyonu şüphesi tespit edildi. Olgular kalça, diz ve omuz çevresi yerleşimli idi. 10 hasta erkek (\% 63) 6 hasta kadındı (\% 37). Ortalama yaş 56(18-81) idi. Hastaların hepsinde direkt grafi ve MRG tetkikleri yardımı ile yumuşak doku sarkomunun boyutu, kemiği çevreleme miktarı, ekleme uzanım, kemiğe invazyon ve medullada kontrast tutulum durumu değerlendirildi. YDS' nın longitüdinal uzunluğu ortalama $14.5 \mathrm{~cm}$ (10.5-23) idi. American Joint Committee on Cancer (AJCC) (9) evreleme sistemine göre 4 hasta da tümör stage IIa, 9 hasta da stage III, 3 hasta da ise stage IV yani uzak metastaz mevcuttu. Sinovyal sarkomlu üç ve malign periferik sinir k1lıfı tümörlü bir hasta ameliyat öncesi kemoterapi (KT) alırken liposarkom hastaları hariç 11 hasta ameliyat sonrası KT aldı. Klinik uygulamamız gereği hastaların tamamı ameliyat sonrasi RT almaktadır. Multidisipliner bir yaklaşımla medikal onkoloji ve RT kliniklerinin de görüşü alınılarak ameliyata karar verilmiştir.

\section{Cerrahi Teknik}

Operasyon sırasında kemik invazyonu şüphesi olması ve tümörün kemiği yarıdan fazla çevrelemesi nedeniyle, proksimal femur yerleşimli 8 hastamızdan 6 tanesine, distal femur yerleşimli 5 hastamızdan 4'üne, proksimal humerus ve tibia yerleşimli 3 hastamıza tümör rezeksiyonu ve çimentolu tümör rezeksiyon protezi ile rekonstrüksiyon uyguladık. Proksimal femur yerleşimli 2, distal femur yerleşimli 1 hastada ise operasyon sırasında tümörün kemik periostundan rahatça styrılabildiği ve invazyon şüphesinin olmadığ görülerek geniş rezeksiyon uygulandı. 
Pleomorfik sarkomlu bir hastamıda operasyon sirasinda femoral arterin tümörün içinde olması nedeniyle damar eksize edilerek, prostetik vasküler greft ile rekonstrüksiyon yapıld1. Bir liposarkomlu hastamızda ise operasyon sirasinda femoral sinirin tümörün içinde olması nedeniyle sinir eksizyonu yapılmak zorunda kalındı. Diğer vakalarda ise tümör damar sinir paketinden kolaylıkla siyrıld1. Gluteus medius trokanter majöre yeniden tespit edildi. Proksimal tibia rezeksiyon protezi uygulanan hastaya medial gastroknemius kas flebi çevrildi.

\section{Postoperatif takip}

Proksimal femur rezeksiyon protezi yapilan hastalara 3 hafta yatak istirahati uygulandi. Kalçaların adduksiyona almaları engellendi. Yatakta kuadriseps kas güçlendirme egzersizlerine hemen başlandi. 3. hafta sonunda hastalar öncelikle yürüteç ile destekli olarak mobilize edildi. Hastalara 3 hafta süre ile düşük molekül ağırlıklı heparin (Enoxaparin 4000 iü/gün) tedavisi başlandi. Sonrasinda aspirin ile tedaviye devam edildi. Distal femur tümör rezeksiyon protezi yapılan hastalara yine ameliyat sonras1 1. gün yatakta kuadriseps egzersizlerine başlanırken 1 hafta sonra hastalar mobilize edildi. Proksimal tibia tümör rezeksiyon protezi yapılan hasta ameliyat sonras1 1. hafta mobilize edildi. Hastaya menteşeli dizlik takılarak ilk etapta 30 derece fleksiyona izin verildi. Haftalık diz fleksiyon dereceleri tedricen arttırıldı. Proksimal humerus rezeksiyon protezi yaptığımız hastalara ameliyat sonrası 3 . gün pasif omuz egzersizlerine başlanırken omuz tam hareketlerine 4. hafta sonunda izin verildi. Periyodik takipler direkt grafi ve bilgisayarlı akciğer tomoğrafisi ile en az 2 y1l 3 ayda bir aralıklar ile yapildı.

\section{İstatistiksel analiz}

Bütün istatistiksel analizler IBM SPSS 22.0 statistical software (IBM Corp., Armonk, NY, USA) proğram kullanılarak yapıldı. Tanımlayıc1 istatistik ortalama \pm standart sapma, siklık, yüzde ve Musculoskeletal Tumor Society (MSTS) fonksiyonel oranlama sistemi (10) ekstremite fonksiyonlarının geri dönüşümünün değerlendirilmesin de kullanıldı.

\section{BULGULAR}

Histolojik tanilar sirasiyla 7 hastada Pleomorfik sarkom (\% 43) (PS) (Resim 1), 4 hastada liposarkom (\%25) (LS), 3 hastada sinovyal sarkom (\% 18) (SS) (Resim 2), 1'er hastada alveolar soft sarkom (\%7) (ASS) ve maliğn periferal sinir kılıfı tümörü (\%7) (MPSKT) idi. Kemik tutulumu şüphesi olan hastalarımızdan; 8 tanesi proksimal femur (Resim 3), 5 tanesi distal femur, 2 tanesi proksimal humerus ve 1 tanesi proksimal tibia yerleşimli idi. Tüm hastaların ameliyat sonrası patoloji raporları incelendiğinde 3 hastada ( 2 hasta pleomorfik sarkom, 1 hasta sinovyal sarkom) kemik doku ile devamlılık olduğu görüldü.

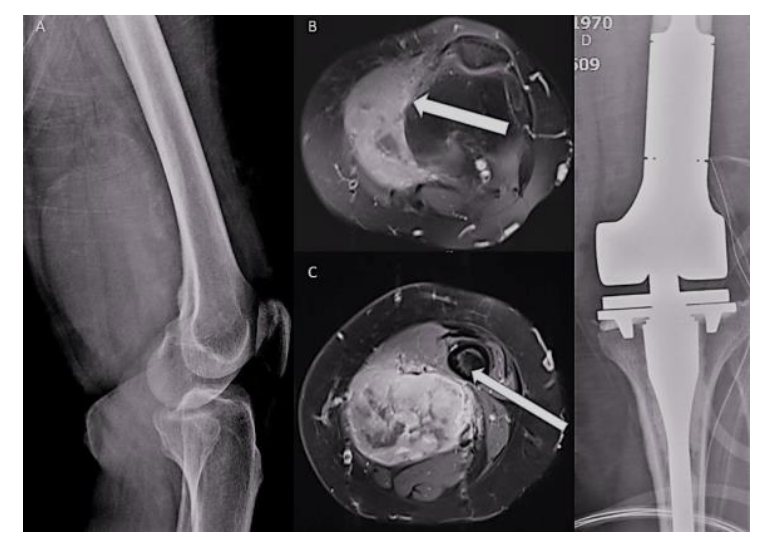

Resim 1.Femur distal pleomorfik sarkom olgusu(A)Lateral direkt grafi. (B)Aksiyel MRG. Beyaz ok kitlenin kemik korteks ile olan ilişkisini göstermektedir. (C)Aksiyel MRG. Beyaz ok meduller dansite değişikliğini göstermektedir. (D)Ameliyat sonrası AP direkt grafi

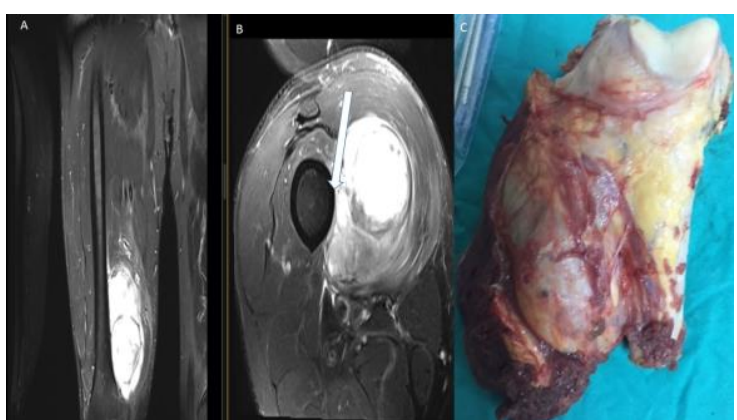

Resim 2. Femur distal liposarkom olgusu (A) Koronal MRG'sü (B)Aksiyel MRG'sü Beyaz ok tümörün kemik dokuya bitişik olduğunu göstermektedir (C) Kitlenin kemik doku ile birlikte çıkarılmış ameliyat sırasındaki görüntüsü 


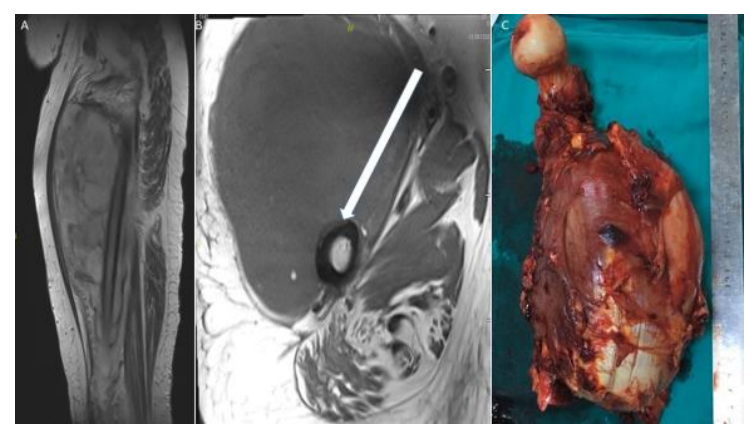

Resim 3. Femur proksimal pleomorfik sarkom olgusu (A) Olgunun koronal MRG'sü. (B) Aksiyel MRG'sü. Beyaz ok kitlenin kemik korteks invazyonunu göstermektedir (C) Ameliyat sırasında kitlenin kemik doku ile çıkartılmış görünümü.

\section{Onkolojik ve Fonksiyonel Sonuçlar}

2 hasta da 8 ve 12. ayda lokal nüks görüldü. Bunlar yüksek dereceli Pleomorfik sarkom (distal femur ve proksimal tibia) hastaları idi. Her iki hastaya yapılan incelemelerde damar sinir tutulumu olması nedeniyle ampütasyon önerildi. Hastalar kabul etmedi. Takiplerde hastalar akciğer metastazına bağlı komplikasyonlardan dolayı kaybedildi. Ortalama takip süresi 22 ay (7-90) $\mathrm{d}$. Hastaların ortalama yaşam süresi 25 (7-82) ay olarak hesaplandi. Hastaların MSTS skorları proksimal femur için 90\% ( 88\%-94\%), distal femur için $82 \% \quad(70 \%-94 \%)$, proksimal humerus için $72 \%(65 \%-76 \%)$ ve proksimal tibia için \% 45 idi.

\section{Komplikasyonlar}

3 hastaya yara yeri problemi ve enfeksiyon şüphesi nedeniyle debritman uygulandi. Ameliyat sonrası antibiyotik tedavisine devam edildi. Hastalar sorunsuz iyileşti. Yine endoprotez yapılan 1 hastada ameliyat sonras1 1. ayda kalça protezi çıkığı gelişti. Çıkık kapalı olarak redükte edilerek hasta 3 hafta ilgili ektremiteye AFO (Ayak Foot Ortez) takılarak istirahate alınd.

\section{TARTIŞMA}

Yumuşak doku sarkomları belirli bir boyuta geldikten sonra siklıkla ekstrakompartmantal bir hal alırlar. Tümör etrafinda bulunan derin fasia, kıkırdak ve kemik periosteum sıklıkla tümörün yayılmasına engelleyici bir bariyer oluşturan yapılardır. YDS' ları yakın planda olan kemik doku, damar ve sinir yapılarına invazyon gösterebilirler (11). MRG yumuşak doku tümörlerinin ekstremite koruyucu cerrahi tedavisinin planlanmasında, özellikle tümörün çevre kemik doku, damar ve sinir yapıları ile ilişkisini göstermesi bakımından son derece önemli bir tetkiktir. Yumuşak doku sarkomlarının kemik doku ile ilişkisi birkaç şekilde olabilmektedir. İlki tümör kemik dokuya bitişiktir ve genellikle bunun anlamı tümör ile kemik arasında doku kalmamıştır. Kemik dokuya invazyon durumuna MRG ile karar verilir. İkincisinde tümör genellikle kemiğin etrafını yarıdan fazla sarmıştır. Üçüncüsün de ise tümör kemik korteks te destrüksiyon yapmıştır. Bunun anlamı medüller kavitede sinyal değişiklikleri mevcut ya da medüller kaviteye tümör penetre olmuştur. Klinik çalışmalara bakıldığında yumuşak doku sarkomlarının kemik invazyon sıklığı \% 5-10 dur ve sağkalım için kötü bir prognostik faktördür $(11,12)$.

Genellikle ilk durumda tümörün kemikten subperiostal siyrilmasının, yeterli negatif cerrahi sınır sağladığına ve periostun tümör büyümesi için engelleyici bir bariyer olduğuna inanılır. Fakat 2. ve 3. durumlarda tedavi şekli cerrahlar için bir problem oluşturabilmektedir. Özellikle eklem çevresi yerleşimli olgularda tümör kas, tendon ve damar sinir yapılarına çok yakın veya fikse durumda olabilmektedir. $\mathrm{Bu}$ nedenle ekleme yakın yerleşimli tümörlerde anatomik yapılardan dolayı geniş bir cerrahi rezeksiyon yapmak güç olabilmektedir. $\mathrm{Bu}$ tümörlerde ekstremite koruyucu cerrahi yapmak için ön koşul, cerrahi sınır negatifliğini sağlamak ve bu şekilde lokal nüks olasılığını azaltmaktır. YDS'da ameliyat öncesi RT ve KT verilmesinin tedavide etkinliğini tam olarak gösteren net çalışmalar yoktur $(13,14)$. Cerrahi prosedürün ve uygulanacak cerrahi rekonstrüksiyon tipi, damar sinir oluşumlarının korunabilmesi son derece önemlidir.

Çalışmamızda diz, kalça ve humerus çevresi yerleşimli yumuşak doku sarkomu olan 16 hastanın çevre dokular ve kemik yapı ile olan ilişkisi ameliyat öncesi çekilen direkt grafi ve MRG ile değerlendirildi. Tümörlerin tamamı $10 \mathrm{~cm}$ ' nin üzerinde kemik kortekse dayanmış veya invazyon şüphesi mevcut ve damar sinir yapılarına çok yakındı. Kemik doku invazyonu şüphesi olan ve kemiğin etrafını yarıdan fazla sarmış hastalar da 
yumuşak doku tümörü kemik doku ile birlikte çıkartılıp, endoprotez ile rekonstrüksiyon yapildı. Hastalardan ameliyat sonras1 patolojilerinde 3'ünde kemik doku ile devamlılığın olduğu görüldü.

Kalça protezi yapılan ameliyatlar da eklem kapsülü mümkün olduğu kadar korunarak protez sonrası kapsül yeniden dikilmelidir. Donati ve arkadaşları (15) 27 proksimal femur yerleşimli kemik tümörü olgusunda prostetik allogreft kullanmış fakat bu vakalardan 17 tanesinde trokanter majörde kırık meydana geldiğini bildirmişlerdir. Biz de allogreft kullanılan vakalarda karşılaşılan bu sorunlardan dolayı gluteus mediusu az bir kemik doku ile birlikte birakarak endoproteze yeniden tespit ettik. Bu şekilde abdüktör mekanizmay1 koruyarak, maksimum abduksiyon elde etmeye ve kalça çıkığ 1 riskini en aza indirmeye çalıştık.

Malign karakterli de olsa, iyi diferansiye LP vakaların da tümörün kemikten sıyrılması yeterli olmakla birlikte SS, PS, MPSKT gibi daha agresif tümörlerde tümör kemik çevresini sarması durumunda, tümör bitişiğindeki komşu kemik doku ile birlikte eksize edilmelidir. Çünkü bu tümörler, yüksek dereceli ve biyolojik olarak diğer tümörlerden daha agresif seyirli oldukları için büyük olasılıkla, kortikal kemik veya medüller invazyon yapma olasılıkları yüksektir $(14,16)$.

Ferguson ve arkadaşları ise 874 vakalık YDS serilerinde 48 vakada kemik invazyonu saptamışlar ve bu tümörlerin genellikle büyük çaplı, derin yerleşimli ve sıklıkla uzak metastaz ile birlikte olduklarını belirtmişlerdir (11). Panicek ve arkadaşları ise yapmış oldukları çalışmada MRG de kemik invazyonu işaret eden bulguların, lokal veya sistemik nüks ile ilişkisinin olmadığını fakat bu hastalarda yaşam beklentisinin daha düşük olduğunu belirtmişlerdir (1). Gerrand ve arkadaşları bu hastalarda pozitif cerrahi sınırın nüks için bir risk faktörü olduğunu ifade etmekle birlikte, negatif cerrahi sinırla tedavi edilen hastalarda ki lokal nüks olasılı̆̆ının, damar sinir veya kemik yakınlığı nedeniyle sıyrılarak çıkarılan ve planlı pozitif denilen olgulardaki nüks olasılığına yakın olduğunu belirtmiştir (17). Biz tümör kemik üzerinde hareketli ve kemiğin etrafını yarıdan fazla sarmamış ise subperiostal olarak diseke etmekteyiz. Klinik olarak ta bu vakalarda periosteal tabakanın intakt olduğunu ve kemikten kolaylıkla sıyrıldığını gördük.

Yumuşak doku sarkomlarında tümörün büyüklüğü, derinliği ve histopatolojik greydi metastatik durumu ve sağkalımı belirleyen en önemli faktörlerdir. Kemikte invazyon varlığ toplam yaşam süresini azaltan bağımsız bir faktör olduğu Cox çalışmalarında gösterilmiştir. Fakat kemik invazyonu olan hastalarda prognozun daha kötü olacağı da bir gerçektir (11).

Sonuç olarak ameliyat öncesi direkt grafi ve MRG tetkiklerinde kemik invazyon şüphesi olan, YDS'lu hastaların tedavisinin planlanmasinda operasyon sirasinda tümör rezeksiyon protezi hazır bulundurulmalıdır. Tümöral doku, çevre dokular ve damar sinir yapılarından geniş bir şekilde diseke edilerek kemik periosta kadar siyrılmalıdır. YDS'u kemik üzerinde mobil rahat hareket ettirilebiliyor ise, tümör periosttan siyrilarak ekstremite koruyucu cerrahi yapılmaya çalışılmalıdır. MRG tetkiklerinde kemik invazyon şüphesi olan ve tümörün kemik etrafını yarıdan fazla sardığ 1 sert-fikse olgularda ise tümör kemik doku ile birlikte rezeke edilmeli ve endoprotez ile rekonstrüksiyon yapılmalıdır. Kemik invazyonu sağkalım açısından kötü bir prognostik faktördür.

\section{REFERANSLAR}

1. Panicek DM, Go SD, Healey JH, Leung DH, Brennan MF, Lewis JJ. Soft-tissue sarcoma involving bone or neuro vascular structures: MR imaging prognostic factors. Radiology. 1997;205:871-75

2. Panicek DM, Gatsonis C, Rosenthal DI, et al. $\mathrm{CT}$ and MR imaging in the local staging of primary malignant musculoskeletal neoplasms: Report of the Radiology Diagnostic Oncology Group. Radiology. 1997;202: 237-46.

3. LeVay J, O'Sullivan B, Catton C, et al. Outcome and prognostic factors in soft tissue sarcoma in the adult. Int J Radiat Oncol Biol Phys. 1993;27: 1091-1099.

4. Williard WC, Collin C, Casper ES, Hajdu SI, Brennan MF. The changing role of amputation for soft tissue sarcoma of the extremity in adults. Surg Gynecol Obstet. 1992;175:389-96.

5. Williard WC, Hajdu SI, Casper ES, Brennan MF. Comparison of amputation with limbsparing operations for adult soft tissue sarcoma of the extremity. Ann Surg. 1992;215:269-75.

6. Bell RS, O'Sullivan B, Liu FF, et al. The surgical margin in soft-tissue sarcoma. J Bone Joint Surg Am. 1989;71: 370-75. 
7. Davidson T, Cooke J, Parsons C, Westbury G. Pre-operative assessment of soft tissue sarcomas by computed tomography. Br J Surg. 1987;74: 474-78.

8. Stojadinovic A, Leung DHY, Allen P, et al. Primary adult soft tissue sarcoma: timedependent influence of prognostic variables. J Clin Oncol 2002;20: 4344-52

9. Greene FL, Page DL, Fleming ID, et al, editors. American Joint Committee on Cancer: Cancer Staging Manual. 6th ed. New York: Springer; 2002: 221-6.

10. Enneking WF, Dunham W, Gebhardt MC, Malawar M, Pritchard DJ. A system for the functional evaluation of reconstructive procedure safter surgical treatment of tumors of the musculoskeletal system. Clin Orthop Relat Res 1993;286:241-6

11. Ferguson PC, Griffin AM, O'Sullivan B, et al. Bone invasion in extremity soft-tissue sarcoma: impact on disease out comes. Cancer 2006; 106:2692-700

12. Sawamura C, Springfield DS, Marcus KJ, Perez-Atayde AR, Gebhardt MC. Factors predicting local recurrence, metastasis, and survival in pediatric soft tissue sarcoma in extremities. Clin Orthop Relat Res 2010;468: 3019-27

13. Blay J-Y, Le Cesne A. Adjuvant chemotherapy in localized soft tissue sarcomas: still not proven. The Oncologist 2009; 14: 1013-20

14. Reynoso D, Subbiah V, Trent JC, et al. Neoadjuvant treatment of soft-tissue sarcoma: a multimodality approach. J Surg Oncol 2010;101:327-33

15. Donati D, Giacomini S, Gozzi E, Mercuri M. Proximal femur reconstruction by an allograft prosthesis composite. Clin Orthop Relat Res 2009; 394:192-200

16. Stucky C-CH, Johnson KN, Gray RJ, et al. Malignant peripheral nevre sheath tumors (MPNST): The Mayo Clinic experience. Ann Surg Oncol 2012;19: 878-85

17. Gerrand $\mathrm{CH}$, Wunder JS, Kandel RA, et al. Classification of positive magrin safter resection of soft-tissue sarcoma of the limb predicts the risk of local recurrence. $\mathrm{J}$ Bone Joint Surg Br. 2001;83: 1149-55. 